\title{
DEFISIT PRAGMATIK TUTURAN PENDERITA SKIZOFRENIA DI RS JIWA MENUR SURABAYA: KAJIAN PRAGMATIK KLINIS
}

\author{
Yunita Suryani \\ Pascasarjana, Universitas Negeri Surabaya \\ Email: yunita.suryani@mhs.unesa.ac.id
}

\begin{abstract}
Abstrak
Defisit pragmatik adalah ketidaksempurnaan berbahasa yang disebabkan oleh banyak faktor. Salah satu faktor penyebab seseorang mengalami ketidaksempurnaan berbahasa adalah faktor medis. Penelitian ini terfokus pada (1) defisit tindak tutur penderita skizofrenia, (2) defisit deiksis luar tuturan (eksofora) tuturan penderita skizofrenia, (3) defisit struktur percakapan penderita skizofrenia, (4) defisit relevansi tuturan penderita skizofrenia, dan (5) terapeutik terhadap defisit pragmatik tuturan penderita skizofrenia. Penelitian ini dirumuskan dan diperikan berdasarkan gejala pertuturan yang sebenarnya terdapat pada fakta kebahasaan sebagaimana terdapat dalam pemakaian bahasa yang sebenarnya, sehingga penelitian bahasa ini bersifat deskriptif kualitatif. Subjek penelitian ini adalah penderita skizofrenia studi kasus terhadap pasien di RS Jiwa Menur Surabaya bernama Yt. Data pada penelitian ini berupa tuturan yang didapatkan melalui tahapan perekaman, transkripsi, pereduksian, klasifikasi dan interpretasi sehingga mampu menghasilkan deskripsi pada fokus yang telah diajukan. Pada hasil penelitian ini ditunjukkan bahwa (1) Yt mengalami ketidaksempurnaan dalam tindak tutur representatif, direktif, ekspresif, komisif, dan deklaratif; (2) Yt mengalami ketidaksempurnaan dalam merujuk suatu hal berkaitan dengan ruang, persona, dan waktu; (3) Yt mengalami ketidaksempurnaan memahami stuktur percakapan berupa alih tutur (turn taking), tumpang tindih tuturan (overlap), dan pasangan ujaran terdekat (adjacency pairs); (4) Yt mengalami ketidaksempurnaan merelevansikan tuturan; (5) terapeutik membantu memulihkan gangguan berpikir yang diderita Yt.
\end{abstract}

Kata kunci: defisit pragmatik, tuturan penderita skizofrenia

\begin{abstract}
Pragmatic deficits are language imperfections caused by many factors. One of the factors causing a person to experience language imperfection is a medical factor. This study focused on (1) schizophrenic speech deficits, (2) deficits of external deixis (ecofora) schizophrenic speech, (3) deficit of schizophrenic conversation structure, (4) deficits of schizophrenic speech relevance, and (5) therapeutic against the pragmatic deficit of schizophrenic speech. This research is formulated and illustrated based on the actual phrase of speech found in linguistic facts as
\end{abstract}


found in actual language usage, so that the research of this language is descriptive qualitative. The subject of this study is schizophrenic case study of patients in RSU Meniran Surabaya named Yt. The data in this research is a speech obtained through recording, transcription, reduction, classification and interpretation so as to produce a description of the focus that has been proposed. In the results of this study indicated that (1) Yt experience imperfections in acts of speech representative, directive, expressive, commissive, and declarative; (2) Yt experiencing imperfections in referring to a matter related to space, persona, and time; (3) Yt experiencing imperfections in understanding the structure of the conversation in the form of turning, overlap, and adjacency pairs; (4) Yt experiencing imperfections of revealing speech; (5) therapeutic helps restore the thought disorder suffered by Yt.

Keywords: reading prolicity, librarian, educational institutions.

\section{PENDAHULUAN}

Gangguan berpikir secara medis termasuk dalam golongan psikosis. Psikosis adalah gangguan psikis yang menyerang kepribadian seseorang. Gangguan tersebut tampak pada pikiran, emosi, bahasa dan perilaku penderita. Gangguan berpikir psikosis dikelompokkan menjadi dua, yaitu psikosis organik dan psikosis fungsional.

Psikosis organik adalah gangguan psikis yang disebabkan adanya kelainan pada struktur otak, di antaranya tumor otak, kelainan pembuluh darah di otak, infeksi di otak, intoksikasi, dsb. Psikosis fungsional adalah gangguan psikis disebabkan terganggunya fungsi sistem penghantar sinyal sel-sel saraf (neurotransmitter), ada kalanya disertai dengan kerusakan struktur otak. Kelompok psikosis fungsional di antaranya skizofrenia, afektif berat dan manik depresif.

Psikosis yang dikaji dalam penelitian ini adalah psikosis fungsional pada penderita skizofrenia. Menurut Carson dan Butcher (Wiramihardja, 2005:134) skizofreniamerupakan kelompok psikosis yang ditandai terutama oleh distorsidistorsi mengenai realitas, juga sering terlihat adanya perilaku menarik diri dari interaksi sosial, serta disorganisasi dan fragmentasi dalam hal persepsi, pikiran, dan kognisi.

106 | ISSN: 22477-5150 http://journal.unesa.ac.id/index.php/jpi 
Skizofrenia merupakan gangguan mental yang paling umum dan paling serius, karena menimpa satu di antara seratus orang (Cummings, 2007: 432). Skizofrenia dalam pandangan masyarakat disebut gila. Pandangan tersebut menimbulkan rasa takut, kesalahpahaman, dan penghukuman oleh masyarakat.

Gangguan berpikir penderita skizofrenia disebabkan ketidakteraturan kerja sistem neurotransmiter dan kerusakan struktur otak korteks prefrontalis. Ketidakmampuan menghadapi masalah sosial merupakan pemicu seseorang menderita skizofrenia. Gangguan berpikir yang dipicu oleh masalah sosial mengakibatkan penderita mengalami defisit berbahasa.

Ketidaksempurnaan berbahasa penderita skizofrenia dalam penelitian ini dinyatakan dengan defisit pragmatik. Defisit Pragmatik Tuturan Penderita Skizofrenia di RS Jiwa Menur Surabaya dikaji dengan pragmatik klinis. Pragmatik klinis dalam penelitian ini dirujuk dari indikator penilaian (assesment)Pragmatic Protocol Prutting dan Kirchner (1987) terhadap penderita gangguan berbahasa.

Indikator penilaian protokol pragmatis meliputi penilaian aspek verbal, aspek paralinguistik dan aspek nonverbal. Indikator penilaian protokol pragmatik dalam penelitian ini menghasilkan deskripsi defisit verbal dengan indikator nonverbal untuk mendukung konteks tuturan. Defisit verbal dengan kajian pragmatik klinis dalam penelitian ini meliputi defisit tindak tutur, defisit deiksis luar tuturan (eksofora), defisit alih tutur dan defisit relevansi tuturan. Defisit nonverbal sebagai indikator penentu deiksis luar tuturan meliputi kinesik dan proksemik (Maulana, 2009).

Gangguan berpikir penderita skizofenia dapat ditangani secara biomedis oleh dokter dengan pemberian obat-obatan antipsikotik, penanganan psikososial oleh psikolog dan terapeutik oleh perawat serta dukungan dari orang-orang yang tinggal disekitar penderita khususnya keluarga. Defisit bahasa penderita skizofrenia dapat pulih seiring dengan pengobatan, penanganan psikososial, terapeutik dari ahli medis serta dukungan dari keluarga (Darma, 2009). 


\section{Metode Penelitian}

Penelitian ini merupakan penelitian deskriptif karena dirumuskan dan diperikan berdasarkan fakta kebahasaan sebagaimana terdapat dalam pemakaian bahasa yang sebenarnya. Pendekatan yang digunakan dalam penelitian ini adalah pendekatan kualitatif. Pendekatan kualitatif memiliki pola penelitian berparadigma metodologis induktif, yaitu suatu paradigma yang bertitik tolak dari yang khusus ke yang umum. Konseptualisasi, kategorisasi, dan deskripsi dikembangkan atas dasar kejadian yang terjadi di lokasi penelitian (Mahsun, 2005: 30). Sumber data berasal dari tuturan Yt di Ruang Gelatik pasien khusus laki-laki- RS Jiwa Menur Surabaya. Pengumpulan data dalam penelitian ini melalui observasi terlibat, teknik perekaman, teknik elisitasi atau pemancingan, serta wawancara tidak terstruktur. Metode analisis data yang digunakan dalam penelitian ini adalah metode padan dan metode agih (Denzin, 2000).

\section{HASIL PENELITIAN}

\subsection{Defisit Tindak Tutur Penderita Skizofrenia}

\section{1) Defisit tindak tutur representatif}

Tindak tutur representatif Yt ditemukan dalam tuturan mengakui, menunjukkan, dan memberikan kesaksian tentang sesuatu hal yang menurutnya benar. Tindak tutur tersebut mengalami defisit atau ketidaksempurnaan ketika sesuatu hal yang diakui, ditunjukkan, dan kesaksian yang diberikan tersebut tidak tidak nyata ada dan terjadi.

Data (1) berikut merupakan defisit tindak tutur representatif memberi kesaksian.

\begin{tabular}{|l|l|}
\hline \multicolumn{1}{|c|}{$(1)$} & \multicolumn{1}{|c|}{ Interpretasi } \\
\hline $\begin{array}{l}\text { Yt : (a) ... Kula biyen tahu dipethuki cahaya } \\
\text { Saya dulu pernah didatangi cahaya putih nangis. }\end{array}$ & $\begin{array}{l}\text { Yt : Saya dulu pernah didatangi } \\
\text { cahaya putih sedang menangis. }\end{array}$ \\
Pen : (b) Cahaya putih dari mana? & \\
\hline
\end{tabular}

108 | ISSN: 22477-5150 http://journal.unesa.ac.id/index.php/jpi 


\begin{tabular}{l|l} 
Yt : (c) Cahaya putih, di mushola. Gelap gak & Pen : Cahaya putih datang dari \\
Cahaya putih, di mushola. Gelap tidak & mana? \\
ada lampu. Bengi-bengi. Jombang terus & \\
ada lampu. Malam-malam. Jombang lalu & Yt : Cahaya putih, di mushola. \\
padhang. Terus tambah, rumahe mbahku & Gelap tidak ada cahaya lampu. \\
menyala. Terus kemudian, rumahnya kakekku & Malam-malam. Kemudian \\
tahu diparani kiamat barang kok. Aku & Jombang bersinar terang. Lalu \\
pernah didatangi kiamat juga kok. Aku & kemudian, rumah kakekku \\
Iho, dimasuki ular. & pernah didatangi kiamat juga \\
Iho, dimasuki ular. & kok. Aku Iho, tubuhku pernah \\
& dimasuki ular. \\
\hline
\end{tabular}

\section{Konteks}

Saat tuturan berlangsung, Yt duduk di kursi. Yt tidak menatap wajah Pen. Yt bertutur dengan pandangan yang kosong, menatap ke depan, ke arah taman.

(DTTr.Yt.01)

Data (1) tuturan (a) merupakan tindak tutur representatif memberi kesaksian, bahwa Yt pernah didatangi cahaya putih yang menangis. Yt pada tuturan (c) juga menyatakan bahwa cahaya putih yang dia lihat tersebut datang ketika mushola dalam keadaan gelap saat malam hari. Yt juga memberi kesaksian bahwa cahaya putih tersebut menyinari daerah Jombang. Kemudian Yt memberi kesaksian bahwa rumah kakeknya juga pernah didatangi kiamat. Selanjutnya Yt memberi kesaksian bahwa dirinya pernah dirasuki ular. Apabila dideskripsikan dalam bentuk bagan, maka akan tampak sebagai berikut.

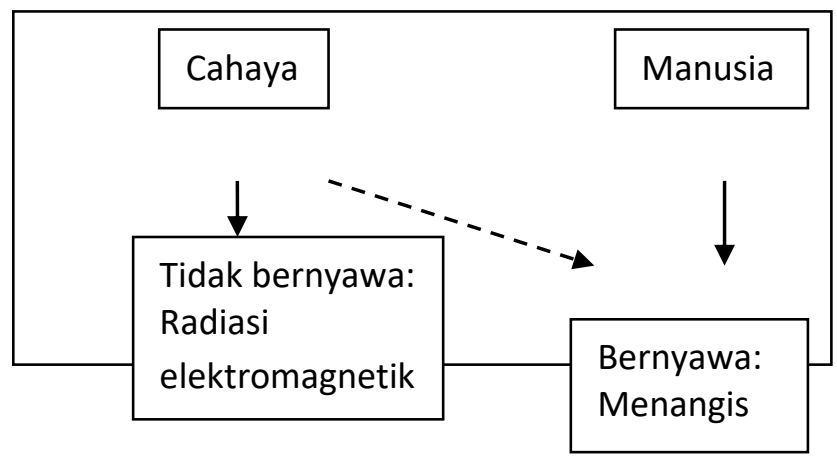

Data (1) Yt sebagai $n$ dan Pen sebagai t. Tuturan $n$ pada data (1) mengalami defisit tindak tutur representatif memberi kesaksian. Kesaksian yang diberikan oleh $\mathrm{n}$ pada tuturan (a) tidak dapat diterima oleh t. Cahaya adalah radiasi elektromagnetik yang dapat dideteksi oleh mata manusia. Menangis adalah 
bentuk kata kerja yang hanya dapat dilakukan oleh makhluk hidup yaitu manusia dan hewan. Sedangkan cahaya adalah kata sifat, tidak bernyawa dan tidak merujuk pada insan atau makhluk hidup yang dapat menangis. Begitupula kata kerja pasif didatangi hanya dapat dilakukan oleh makhluk hidup yang bergerak. Didatangi cahaya secara konotatif sering digunakan untuk menulis karya sastra seperti puisi yang dapat bermakna mendapat pencerahan atau menuju kehidupan yang lebih baik. Sedangkan secara denotatif, didatangi cahaya adalah bentuk lain dari disoroti cahaya, dan itu dilakukan oleh orang kedua terhadap orang pertama. Didatangi cahaya pada tuturan $\mathrm{n}$ tersebut tidak bermakna bahwa cahaya tersebut disorotkan oleh orang lain kepada $n$, namun cahaya yang mendatanginya merujuk pada insan atau makhluk hidup yang dapat menangis. Berdasarkan daya mental $\mathrm{t}$, kesaksian yang diberikan oleh $\mathrm{n}$ tidak dapat diterima oleh t. Saat itu $\mathrm{n}$ mengalami gangguan berpikir berupa konkretisasi, yaitu $\mathrm{n}$ memahami bahwa cahaya dapat menyinari tempat yang gelap ketika malam hari, namun $\mathrm{n}$ tidak memahami bahwa cahaya bukanlah makhluk hidup yang dapat menangis.

Defisit tindak tutur representatif selanjutnya adalah $\mathrm{n}$ memberi kesaksian bahwa rumah kakeknya pernah didatangi oleh kiamat. Pengertian kiamat dalam agama Islam yang dianut oleh $\mathrm{n}$ adalah suatu peristiwa atau kejadian berupa musnahnya seluruh alam, bumi dan isinya. Kiamat tidak hanya menimpa satu atau beberapa orang manusia saja, tetapi menimpa seluruh manusia secara bersamaan dan tidak ada seorang makhluk pun yang dapat selamat. Sehingga tuturan $\mathrm{n}$ tersebut tidak dapat diterima oleh $\mathrm{t}$. Selain itu, $\mathrm{n}$ mengalami halusinasi saat memberi kesaksian bahwa dirinya dirasuki ular.

Data (1) tindak tutur representatif $\mathrm{n}$ menunjukkan kesempurnaan apabila tuturan tersebut sebagai berikut.

*(1) Yt: $\left(a^{1}\right)$... Kula biyen tahu ngerti cahaya putih.

'Saya dulu pernah lihat cahaya putih.'

Pen: $\left(b^{1}\right)$ Cahaya putih dari mana? 
Yt: (c $\left.{ }^{1}\right)$ Cahaya putih lampu di mushola Jombang. Waktu malam hari.

Data $*(1)$ tuturan $\left(a^{1}\right)$ n memberi kesaksian bahwa dirinya pernah melihat cahaya berwarna putih bersinar. Cahaya putih tersebut pada data $\left(c^{1}\right)$ dinyatakan oleh $\mathrm{n}$ adalah cahaya yang berasal dari lampu yang bersinar menerangi mushola yang berada di Jombang pada waktu malam hari.

\section{2) Defisit Tindak Tutur Direktif}

Tindak tutur direktif Yt ditemukan dalam tuturan meminta,dan memerintah. Tindak tutur tersebut mengalami defisit atau ketidaksempurnaan ketika permintaan, perintah dan tantangan yang ditujukan pada mitra tutur tidak dapat dipahami dan tidak dapat diterima oleh mitra tutur. berikut defisit tindak tutur direktif meminta

\begin{tabular}{|c|c|}
\hline (2) & Interpretasi \\
\hline $\begin{array}{l}\text { Per : (a) Yt, kamu suka nggambar kan. Ini } \\
\text { Yt, kamu suka menggambar kan. Ini } \\
\text { tak kasih kertas lagi. Sambil ngobrol ya. } \\
\text { kukasih kertas lagi. Sambil ngobrol ya. } \\
\text { Yt : (b) lya. Sini! (menarik kertas yang } \\
\text { baru dikeluarkan dari map plastik milik } \\
\text { Per) }\end{array}$ & $\begin{array}{l}\text { Per: Yt, kamu suka menggambar } \\
\text { kan. Ini kukasih kertas lagi. Sambil } \\
\text { ngobrol ya. } \\
\text { Yt : lya. Sini! (menarik kertas yang } \\
\text { baru dikeluarkan dari map plastik } \\
\text { milik Per). }\end{array}$ \\
\hline $\begin{array}{l}\text { Yt dan duduk bersebelahan dengan } \\
\text { selembar kertas dari map plastik. Yt ken } \\
\text { disodorkan oleh Per pada Yt. }\end{array}$ & $\begin{array}{l}\text { Per. Yt melihat Per mengeluarkan } \\
\text { udian menarik kertas yang belum }\end{array}$ \\
\hline
\end{tabular}

(DTTd.Yt.02)

Konteks tuturan pada data (2), Per duduk bersebelahan dengan Yt. Per pada tuturan (a) bermaksud mengajak Yt untuk berbincang. Per memberi Yt selembar kertas untuk menggambar dengan harapan agar Yt tidak jenuh dan meninggalkan peristiwa tutur. Yt melihat Per membuka tas punggung dan mengeluarkan map plastik berisi lembaran kertas. Yt pada tuturan (b) menarik 
paksa selembar kertas yang baru dikeluarkan oleh Per dari map plastik tanpa menunggu diberi oleh Per.

Data (2) Per sebagai $n$ dan Yt sebagai t. Defisit deiksis $t$ tampak pada tuturan (b) ketika $\mathrm{t}$ dengan nada tinggi meminta paksa kertas yang belum disodorkan oleh $\mathrm{n}$ pada $\mathrm{t}$. Data (2) tindak tutur direktif t berupa meminta menunjukkan kesempurnaan apabila tuturan tersebut sebagai berikut.

*(2) n: (a $)$ Yt, kamu suka nggambar kan. Ini tak kasih kertas lagi.

Yt, kamu suka menggambar kan. Ini kukasih kertas lagi.

Sambil ngobrol ya.

Sambil ngobrol ya.

t: (bº) lya. Mana? (menunggu $n$ mengeluarkan kertas dari map plastik)

Data $*(4) \mathrm{t}$ menunjukkan kesempurnaan dalam tindak tutur direktif berupa meminta. $\mathrm{t}$ pada tuturan $\left(b^{1}\right)$ bertanya pada $\mathrm{n}$ mengenai pernyataan $\mathrm{n}$ yang bermaksud memberi selembar kertas padanya. Tindakan t pada tuturan $\left(b^{1}\right)$ membiarkan $n$ mengambil selembar kertas dari map plastik dan menunggu $n$ menyodorkan selembar kertas tersebut padanya.

\section{3) Defisit Tindak Tutur Ekspresif}

Tindak tutur ekspresif $\mathrm{Yt}$ ditemukan dalam tuturan mengeluh, dan menyalahkan. Tindak tutur tersebut mengalami defisit atau ketidaksempurnaan ketika keluhan yang disampaikan, dan tindakan menyalahkan diri sendiri atau orang lain tersebut tidak masuk akal. Berikut defisit tindak tutur ekspresif menyalahkan.

Data (3) berikut merupakan defisit tindak tutur ekspresif menyalahkan.

\begin{tabular}{|c|c|}
\hline (3) & Interpretasi \\
\hline $\begin{array}{l}\text { Pen : (a) Unesa itu Universitas Negeri Surabaya. } \\
\text { Yt : (b) Lhe, sampeyan gak ngerti! } \\
\text { Lha, mbak tidak tahu! } \\
\text { (c) Surabaya kan negara Republik }\end{array}$ & $\begin{array}{lr}\quad \text { Pen : } & \text { Unesa itu } \\
\text { Universitas } & \text { Negeri } \\
\text { Surabaya. } & \end{array}$ \\
\hline
\end{tabular}

112 | ISSN: 22477-5150 http://journal.unesa.ac.id/index.php/jpi 


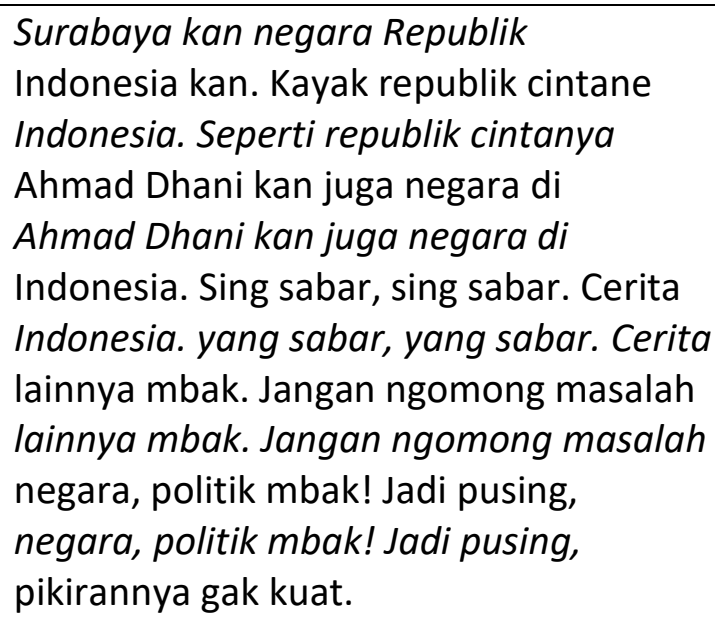

\section{Konteks}

Saat bertutur, Yt duduk dihadapan Pen. Yt pada tuturan sebelumnya mengeja tulisan yang berada di logo almamater Pen.

(DTTe.Yt.03)

Data (3) Pen pada tuturan (a) menyatakan pada Yt bahwa Unesa adalah akronim dari Universitas Negeri Surabaya. Yt pada tuturan (b) menyalahkan tuturan Pen. Yt pada tuturan (c) memperbaiki kesalahan Pen dengan menyatakan bahwa Surabaya adalah negara bagian dari Republik Indonesia seperti republik cinta milik Ahmad Dhani. Selanjutnya Yt mengakhiri tuturannya dengan meminta Pen bercerita hal lain selain berhubungan dengan negara. Membicarakan sesuatu yang berhubungan dengan negara bagi Yt adalah masalah politik yang dapat membuat kepalanya pusing.

Data (3) Pen sebagai $n$ dan Yt sebagai t. Defisit tindak tutur ekspresif Yt berupa menyalahkan tampak pada tuturan (b) dan (c). Yt pada tuturan (b) menyalahkan tuturan $\mathrm{n}$ karena merasa lebih mengetahui dengan bertutur sampeyan gak ngerti. Sedangkan pernyataan $\mathrm{n}$ pada tuturan (a) sudah benar bahwa Unesa adalah akronim dari Universitas Negeri Surabaya. Selanjutnya t pada tuturan (c) bermaksud memperbaiki kesalahan Pen dengan menyatakan bahwa Surabaya adalah negara bagian dari Republik Indonesia seperti manajemen musik republik cinta milik Ahmad Dhani yang juga dinyatakan oleh Yt sebagai bagian dari negara yang ada Indonesia. Surabaya bukanlah negara bagian 
dari Indonesia. Negara merupakan suatu wilayah yang berdiri secara independen dan terdiri atas beberapa wilayah serta daerah. Surabaya adalah nama kota yang berada di propinsi Jawa Timur dan berada di wilayah kepulauan Jawa yang ada di negara Indonesia. Sehingga dapat disimpulkan bahwa Surabaya adalah salah satu kota yang ada di negara Indonesia. Sedangkan republik cinta adalah nama atau label sebuah perusahaan musik yang ada di Indonesia yang dimiliki oleh musisi Indonesia, yaitu Ahmad Dhani.

Tuturan t pada tindak tutur ekspresif berupa menyalahkan menunjukkan kesempurnaan apabila tuturan tersebut sebagai berikut.

*(3) $\mathrm{n} \quad:\left(\mathrm{a}^{1}\right)$ Unesa itu Universitas Negeri Surabaya.

t $\quad:\left(b^{1}\right)$ lya, aku ngerti! ( $\left.c^{1}\right)$ Surabaya bukan negara bagian dari republik Indonesia, tetapi nama kota bagian dari negara Republik Indonesia kan. Kalau republik cintanya Ahmad Dhani itu bukan nama negara yang ada di Indonesia, tetapi nama perusahaan musik.

Data $*(3)$ t pada tuturan $\left(c^{1}\right)$ menunjukkan kesempurnaan dalam tindak tutur ekspresif menyalahkan apabila Surabaya adalah negara bagian dari republik Indonesia. t memerbaikinya dengan menyatakan bahwa Surabaya bukanlah negara bagian dari republik Indonesia, melainkan nama kota bagian dari negara Indonesia. Selanjutnya t juga menyalahkan apabila republik cinta milik Ahmad Dhani adalah negara yang ada di Indonesia. $t$ memerbaiki tuturannya dengan menyatakan bahwa republik cinta milik Ahmad Dhani bukanlah negara bagian Indonesia, melainkan nama perusahaan musik di Indonesia.

\section{4) Tindak Tutur Komisif}

Yt kadangkala memiliki kemampuan memahami maksud ujaran mitra tutur. Hal tersebut tampak pada tuturan Yt yang memberikan respon berupa jawaban atau pernyataan atas tuturan mitra tutur. Namun jawaban atau pernyataan Yt atas tindak tutur komisif yang dituturkan oleh mitra tutur tersebut mengalami 
defisit ketika tuturan Yt tersebut keluar dari topik pembicaraan atau tidak sesuai dengan maksud dan harapan mitra tutur.

\begin{tabular}{|c|c|c|}
\hline \multicolumn{2}{|r|}{ (4) } & Ingterpretasi \\
\hline $\begin{array}{l}\text { Per } \\
\text { Yt }\end{array}$ & $\begin{array}{l}\text { : (a) Satu jam dua jam ngamen dapat } \\
\text { empat puluh? Ya disyukuri loh. } \\
\text { : (b) lya. Di syukuri. Di syukuri terus ya } \\
\text { lya. Di syukuri. Di syukuri terus ya } \\
\text { sakit. Syukur.. syukur... kapok koen! } \\
\text { sakit. Syukur.. syukur.. kapok kamu! } \\
\text { (tertawa) }\end{array}$ & $\begin{array}{l}\text { Per : Satu jam dua } \\
\text { jam mengamen dapat } \\
\text { menghasilkan empat puluh } \\
\text { ribu? Ya disyukuri loh. } \\
\text { Yt: . Di syukuri. Di } \\
\text { syukuri terus ya sakit. } \\
\text { Syukur.. syukur.. kapok } \\
\text { kamu! }\end{array}$ \\
\hline & $\begin{array}{c}\text { Konteks } \\
\text { angsung, Per duduk di ku }\end{array}$ & an Yt berd \\
\hline
\end{tabular}

$$
\text { (DTTk.Yt.4) }
$$

Data (4) Per pada tuturan (a) memuji dan miminta Yt untuk mensyukuri pendapatan yang diperoleh saat mengamen. Yt pada tuturan (b) memahami syukur dalam bahasa Jawa yang merupakan ucapan atau tindakan menertawakan rasa sakit atau penderitaan yang dialami oleh orang lain.

Data (4) Per sebagai $\mathrm{n}$ dan Yt sebagai t. $\mathrm{t}$ mengalami defisit dalam memahami tindak tutur komisif yang dituturkan oleh $n$. $n$ berharap agar $t$ memahami maksud tuturannya bahwa rejeki yang didapat berapapun jumlahnya harus diterima sebagai wujud syukur kepada Tuhan. Namun t ternyata memiliki pemahaman yang berbeda terhadap maksud syukur yang dituturkan oleh $\mathrm{n}$. Sehingga maksud dan harapan tuturan $\mathrm{n}$ tidak diterima dengan baik oleh $\mathrm{t}$.

Tuturan $\mathrm{n}$ pada tindak tutur komisif diterima dengan sempurna oleh $\mathrm{t}$ apabila tuturan $\mathrm{t}$ sebagai berikut.

*(4) $\mathrm{n} \quad$ : (a1) Satu jam dua jam ngamen dapat empat puluh? Ya disyukuri loh.

t $\quad$ : ( $\left.b^{1}\right)$ lya. Di syukuri sebagai wujud terima kasih pada Allah.

Data *(4) t menunjukkan kesempurnaan memahami maksud dan harapan dari tindak tutur komisif yang dituturkan oleh $\mathrm{n}$. t pada tuturan $\left(\mathrm{b}^{1}\right)$ memahami 
maksud syukur yang dituturkan $\mathrm{n}$ dengan menjawab bahwa bersyukur adalah wujud terima kasih pada Tuhan.

\section{5) Tindak Tutur Deklaratif (Isbati)}

Tindak tutur deklaratif Yt ditemukan dalam tuturan melarang, dan mengizinkan. Tindak tutur tersebut mengalami defisit atau ketidaksempurnaan ketika sesuatu hal yang dilarang dan diizinkan oleh Yt berkaitan dengan halusinasi atau waham yang diderita. Berikut defisit tindak tutur deklaratif melarang

Data (12) beeikut merupakan defisit tindak tutur deklaratif melarang.

\begin{tabular}{|l|l|}
\hline \multicolumn{1}{|c|}{ (5) } & \multicolumn{1}{|c|}{ Interpretasi } \\
\hline $\begin{array}{l}\text { Per } \quad \text { (a) Kamu punya ilmu apa aja? Ngilmu di } \\
\text { mana? } \quad \text { (b) Gak tak kasih tahu mbak. Tambah }\end{array}$ & $\begin{array}{l}\text { Per : Kamu punya ilmu gaib } \\
\text { apa saja? Belajar ilmu gaib } \\
\text { di mana? }\end{array}$ \\
$\begin{array}{l}\text { Tidak aku kasih tahu mbak. Daripada } \\
\text { aku keliru kabeh. Nanti tambah aku sing } \\
\text { aku keliru semua. Nanti daripada aku yang } \\
\text { sesat, sampeyan tambah gak kuat, tambah } \\
\text { sesat, mbak daripada tidak kuat, daripada } \\
\text { dadi miring gak kenceng sampeyan. } \\
\text { jadi gila tidak lurus mbak. }\end{array}$ & $\begin{array}{l}\text { Yt : Tidak aku kasih tahu } \\
\text { mbak. Daripada aku keliru } \\
\text { semua. Daripada nanti aku } \\
\text { yang sesat, daripada mbak } \\
\text { tidak mampu, daripada } \\
\text { mbak jadi gila tidak sadar. }\end{array}$ \\
\hline \multicolumn{2}{|c|}{ Kanteks tuturan berlangsung, Yt duduk bersila di kursi sambil meletakkan jari } \\
manis tangan kanannya di keningnya.
\end{tabular}

(DTTi.Yt.5)

Data (5) Per pada tuturan (a) bertanya pada Yt mengenai ilmu gaib yang pernah dipelajari oleh Yt. Per juga bertanya dimana Yt belajar dan memeroleh ilmu gaib tersebut. Yt pada tuturan (b) melarang dan menolak Per mengetahui mengenai ilmu gaib yang pernah dipelajari oleh Yt karena Yt merasa bertanggungjawab apabila terjadi sesuatu pada Per apabila Per mengetahui ilmu gaib yang dimiliki oleh Yt. Yt juga menyatakan jika Per nantinya tidak mampu belajar ilmu gaib dapat membuat Per tersesat bahkan hilang kesadaran. 
Data (5) Per sebagai $\mathrm{n}$ dan $\mathrm{Yt}$ sebagai t. Defisit tindak tutur deklaratif berupa melarang tampak pada tuturan (b) ketika t melarang dan menolak $n$ mengetahu ilmu gaib yang pernah dipelajari t. t menyatakan bahwa dirinya dapat saja keliru mengajarkan ilmu tersebut sehingga membuat $n$ tersesat. Sehingga $t$ merasa bertanggungjawab apabila terjadi sesuatu terhadap $\mathrm{n}$ jika $\mathrm{n}$ mengetahui dan belajar ilmu yang dimiliki oleh $\mathrm{t}$.

Tuturan $\mathrm{t}$ pada tindak tutur deklaratif berupa melarang menunjukkan keempurnaan apabila apabila tuturan t sebagai berikut.

*(5) n: (a') Kamu punya ilmu apa aja? Ngilmu di mana?

t $\quad:\left(b^{1}\right)$ Aku nggak punya ilmu dan nggak ngilmu sesat. Aku tidak punya ilmu dan tidak belajar ilmu sesat.

Tambah keliru kabeh. Nanti tambah sesat, sampeyan

Daripada keliru semua. Daripada nanti menjadi sesat, tambah gak kuat, tambah dadi miring gak kenceng daripada tidak mampu, daripada nanti menjadi gila tidak sadar sampeyan.

mbak.

Data $*(5)$ t menunjukkan kesempurnaan dalam tindak tutur deklaratif berupa melarang. $t$ pada tuturan $\left(b^{1}\right)$ menyatakan bahwa dirinya tidak memiliki ilmu gaib dan tidak belajar ilmu gaib karena ilmu gaib dapat menyesatkan manusia. $\mathrm{t}$ juga melarang $\mathrm{n}$ untuk belajar ilmu gaib agar tidak tersesat bahkan dapat membuat hilang kesadaran.

\subsection{Defisit Deiksis Luar Tuturan (Eksofora) Penderita Skizofrenia}

Defisit deiksis luar tuturan tuturan penderita skizofrenia adalah ketidaksempurnaan berbahasa penderita skizofrenia dalam menunjuk suatu hal yang berada di luar tuturan, meliputi ruang, persona dan waktu karena dipengaruhi halusinasi dan waham. Indikator penentu deiksis luar tuturan penderita skizofrenia adalah nonverbal yang meliputi kinesik dan proksemik. 


\section{1) Defisit Deiksis Ruang Tuturan Penderita Skizofrenia}

Defisit deiksis ruang tuturan penderita skizofrenia terjadi ketika mereka berada di rumah sakit, namun mereka merasa berada di ruang atau tempat lain. Hal tersebut karena pikiran mereka dipengaruhi oleh halusinasi dan waham. Halusinasi dan waham tiap penderita berbeda.

Yt dengan sub tipe skizofrenia tidak terorganisasi dalam penelitian ini memiliki waham kebesaran. Dia merasa bisa menjadi apa saja yang dia kehendaki. Sehingga halusinasi yang muncul mengenai ruang atau tempat keberadaan dia pun berbeda-beda. Berikut defisit deiksis ruang menyatakan lokasi.

\begin{tabular}{|c|c|}
\hline (6) & Interpretasi \\
\hline $\begin{array}{l}\text { Yt : ... (a) Mbak,ITS ya? (melihat logo } \\
\text { almamater Pen) } \\
\text { Pen : (b) Bukan ya. (c) UNESA. } \\
\text { Yt } \quad: \text { (d) Jalan Surabaya sih?! } \\
\text { Pen } \quad: \text { (e) Bukanlah. (f) Ketintang } \\
\text { Yt : (g) Ketintang, sebelahe monumen itu ya. } \\
\text { Ketintang, sebelahnya monumen itu ya. } \\
\text { Pen : (h) Monumen apa? } \\
\text { Yt : (i) Kali ketintang sebelahe kali jiwa. } \\
\text { Kali ketintang sebelahnya kali jiwa. } \\
\text { Pen : (j) Bukan. (k) UNESA itu dekat RS AL } \\
\text { Yt } \quad: \text { (l) Itu kan masih Kupang }\end{array}$ & $\begin{array}{l}\text { Yt : ...Mbak, kuliah di ITS ya? } \\
\text { (melihat logo almamater } \\
\text { Pen) } \\
\text { Pen : Bukan ya. UNESA. } \\
\text { Yt : Jalan Surabaya sih?! } \\
\text { Pen : Bukanlah. Ketintang. } \\
\text { Yt : Ketintang, sampingnya } \\
\text { monumen itu ya. } \\
\text { Pen : Monumen apa? } \\
\text { Yt : Kali ketintang sampinya } \\
\text { kali jiwa. } \\
\text { Pen : Bukan. UNESA itu } \\
\text { dekat RS AL. } \\
\text { Yt : Itu kan masih daerah } \\
\text { Kupang. }\end{array}$ \\
\hline $\begin{array}{l}\text { I. Konteks } \\
\text { Yt berdiri di depan Pen dan melihat logo y } \\
\text { dengan membungkukan badan. Kemudian Yt dudu } \\
\text { melakukan pertuturan mengenai lokasi UNESA. } \\
\text { II. } \quad \text { Yt dengan daya mentalnya memahami ba } \\
\text { berlogo adalah orang yang sedang men }\end{array}$ & $\begin{array}{l}\text { ang tertera di almamater Pen } \\
\text { k di samping Pen. Yt dan Pen } \\
\text { wa orang yang memakai jas } \\
\text { mpuh pendidikan. }\end{array}$ \\
\hline
\end{tabular}

(DR.Yt.6) 
Pada data (6) Yt memulai pertuturan dengan bertanya kepada Pen mengenai tempat Pen menempuh pendidikan. Yt saat itu melihat logo pada almamater Pen, kemudian Yt menyatakan (a) bahwa Pen menempuh pendidikan di ITS. Pen menyatakan (b) untuk menyalahkan pernyataan Yt, kemudian memperbaikinya dengan memberi pernyataan (c) bahwa Pen menempuh pendidikan di UNESA. Yt kemudian memberikan pernyataan (d) bahwa UNESA berada di jalan Surabaya. Pen menyatakan (e) untuk menyalahkan pernyataan Yt, kemudian memperbaikinya dengan memberi pernyataan (f) bahwa UNESA tidak berada di jalan Surabaya, melainkan di Ketintang yang merujuk pada jalan atau alamat. Yt menyatakan (g) bahwa Ketintang terletak di sebelah monumen. Pen menyatakan (h) untuk bertanya pada Yt mengenai monumen yang disebutkan oleh Yt. Monumen yang dirujuk oleh Yt pada pernyataan (i) yaitu monumen Kali Ketintang yang juga bersebelahan dengan Kali Jiwa. Hal ini berarti monumen Kali Ketintang yang dirujuk oleh Yt terletak di antara Ketintang dan Kali Jiwa. Pen menyatakan (j) untuk menyalahkan jawaban Yt dan memperbaikinya serta bermaksud mengakhiri pertuturan mengenai lokasi UNESA dengan memberi pernyataan (k) bahwa UNESA terletak tidak jauh dari RS AL (Angkatan Laut) Dr. Ramelan Surabaya. Kemudian Yt memberikan pernyataan (I) bahwa tempat atau ruang yang dirujuk oleh Pen terletak di wilayah Kupang.

Pada data (6) Yt sebagai $n$ dan Pen sebagai t. pada tuturan tersebut tampak defisit deiksis ruang yang dialami oleh $\mathrm{n}$. Meskipun $\mathrm{n}$ yang tinggal di Jombang cukup mengetahui tempat dan wilayah di Surabaya, namun kemampuan mengingat jalan yang merujuk tempat dan arah tidak sempurna. Pada saat itulah secara medis $n$ mengalami bentuk gangguan berpikir berupa konkritisasi. Hal ini tampak pada kemampuan $\mathrm{n}$ mengetahui ITS yang merujuk pada tempat atau ruang yang berada di Surabaya. $\mathrm{n}$ juga dapat menyebutkan Kupang sebagai salah satu wilayah yang berada di Surabaya. Namun $\mathrm{n}$ mengalami kesulitan mengingat jalan atau lokasi keberadaan tempat atau ruang yang disebutnya. $\mathrm{n}$ pada tuturan 
di atas selalu memberikan pernyataan mengenai ruang atau tempat berupa bangunan maupun lokasi. Gangguan berpikir yang dialami $\mathrm{n}$ membuatnya merasa mengetahui ruang atau tempat yang disebutkan oleh $\mathrm{t}$ namun selalu tidak sempurna atau mengalami defisit.

Defisit deiksis ruang $\mathrm{n}$ tampak pada pernyataan (d) yang menyebutkan bahwa UNESA terletak di jalan Surabaya. Jalan Surabaya di kota Surabaya dalam peta wilayah Surabaya tidak ditemukan. Pada peta wilayah Surabaya, kata yang similar bentuk dengan jalan Surabaya adalah jalan Surabayan yang berada di wilayah Kedung Sari, Surabaya. Sedangkan UNESA tidak berada di jalan Surabayan. UNESA atau Universitas Negeri Surabaya terletak di jalan Ketintang dan jalan Lidah Wetan Surabaya. Berdasarkan daya mental $\mathrm{n}$ yang cukup mengetahui wilayah Surabaya dapat saja memahami silabel terakhir SA dari akronim UNESA sebagai jalan Surabaya.

Defisit deiksis ruang $\mathrm{n}$ juga tampak ketika menyatakan bahwa Ketintang terletak di sebelah monumen. Ketintang pada pernyataan (f) merupakan referen yang merujuk pada jalan atau alamat dipahami berbeda oleh $\mathrm{n}$. Apabila referen Ketintang merujuk pada benda berupa bangunan, maka pernyataan (g) dapat saja benar. Kali Ketintang sebagai referen yang dirujuk oleh $\mathrm{n}$ sebagai monumen tidak berupa bangunan dari tanah liat yang dibentuk sedemikian rupa, namun berupa tempat aliran air yaitu kali yang terdapat di daerah Ketintang. Kali yang berada di sekitar jalan Ketintang memang ada, namun Monumen Kali Ketintang di sekitar UNESA pada konteks yang sebenarnya tidak ada. Selain itu, Kali Jiwa di wilayah UNESA dalam konteks sebenarnya juga tidak ada. Apabila merujuk pada konteks pertuturan mengenai UNESA dan Ketintang yang memang nyata ada, maka monumen yang dirujuk oleh $\mathrm{n}$ dapat saja Monumen Mayangkara yang terletak di dekat Jembatan Wonokromo dan di bantaran Kali Wonokromo yang letaknya tidak jauh dengan Ketintang.

Defisit deiksis ruang Yt selanjutnya tampak pada pernyataan (I) bahwa RS AL merupakan bagian dari wilayah Kupang. RS AL yang dirujuk oleh $t$ adalah $R S$ 120 | ISSN: 22477-5150 http://journal.unesa.ac.id/index.php/jpi 
AL Dr. Ramelan. Rumah sakit tersebut merupakan salah satu rumah sakit besar di Surabaya yang terletak di jalan Gadung, menghadap jalan raya dua arah dan berada di wilayah A. Yani. RS AL mudah dilihat dan diketahui oleh orang yang melalui tempat tersebut. RS AL berhadapan dengan pusat perbelanjaan Royal Plaza.

Ketika merujuk pada RS AL, $\mathrm{t}$ berharap $\mathrm{n}$ dapat mengetahui lokasi keberadaan RS AL sehingga t mudah mengarahkan lokasi keberadaan UNESA yang letaknya berada diseberang RS AL namun dibatasi oleh keberadaan pusat perbelanjaan Royal Plaza. $\mathrm{n}$ memberikan pernyataan (I) bahwa tempat atau ruang yang dirujuk oleh Pen terletak di wilayah Kupang. Sedangkan keberadaan RS AL di wilayah Kupang pada kenyataanya tidak ada. Ciri pembeda referen yang dirujuk oleh $\mathrm{n}$ tampak pada tabel berikut:

\begin{tabular}{|l|l|c|c|c|}
\hline Ciri Pembeda: & ESA & $\begin{array}{l}\text { M.Kali } \\
\text { Ketintang }\end{array}$ & Kali Jiwa & $\begin{array}{l}\text { RS AL } \\
\text { Ramelan }\end{array}$ \\
\hline Jl. Surabaya & - & - & - & - \\
Jl. Ketintang & + & - & - & - \\
Jl. Kupang & - & - & - & - \\
Jl. Raya A.Yani & - & - & - & + \\
\hline
\end{tabular}

Jika $\mathrm{n}$ tidak mengalami gangguan bentuk berpikir konkretisasi mengenai lokasi bangunan, alamat dan arah jalan, maka $\mathrm{n}$ dapat saja memberikan pernyataan:

*(6) Yt $\quad: \ldots\left(a^{1}\right)$ Mbak,ITS ya? (melihat logo almamater Pen)

Pen : $\quad\left(b^{1}\right)$ Bukan ya. $\left(c^{1}\right)$ UNESA.

Yt : $\left(\mathrm{d}^{1}\right)$ Jalan Ketintang sih?!

Pen $:\left(e^{1}\right)$ lya. $\left(f^{1}\right)$ Ketintang

Yt $\quad:\left(\mathrm{g}^{1}\right)$ Ketintang, yang ada monumen itu ya.

Pen : $\left(h^{1}\right)$ Monumen apa?

Yt : ( (i) Mayangkara dekatnya Kali Wonokromo.

Pen $:\left(j^{1}\right)$ lya. $\left(k^{1}\right)$ UNESA itu dekat RS AL

Yt : (I') Itu kan masih A.Yani. Berhadapan dengan mall. 
Data *(6) n menunjukkan kesempurnaan lokasi bangunan, alamat dan arah jalan yang disebutkan oleh t. $\mathrm{n}$ mengetahui lokasi UNESA yang berada di jalan Ketintang dengan menyatakan $\left(d^{1}\right)$. Begitu pula pada pernyataan $\left(g^{1}\right) n$ menunjukkan kesempurnaan menyatakan bahwa di Ketintang terdapat sebuah monumen. Pernyataan $\left(i^{1}\right) n$ menyatakan bahwa monumen yang terdapat di jalan Ketintang adalah Monumen Mayangkara. Jalan Ketintang merupakan bagian dari kelurahan Wonokromo. Jalan menuju UNESA di jalan Ketintang dari arah timur melewati Kali Wonokromo. Sehingga Monumen Mayangkara yang berada didekat Kali Wonokromo dapat saja dinyatakan terletak di jalan Ketintang.

Begitu pula pada pernyataan ( $\left.I^{1}\right) \mathrm{n}$ memahami lokasi yang disebut oleh $\mathrm{t} . \mathrm{n}$ menunjukkan kesempurnaan memahami lokasi RS AL yang dinyatakan ( $\left.k^{1}\right)$ oleh $t$ bahwa UNESA yang berada dekat dengan RS AL terletak di jalan A.Yani (Jl. Raya A.Yani). Selain itu, $t$ juga menyatakan bahwa RS AL berhadapan dengan mall atau pusat perbelanjaan Royal Plaza.

\section{2) Defisit Deiksis Persona Tuturan Penderita Skizofrenia}

Defisit deiksis persona tuturan penderita skizofrenia terjadi ketika mereka bertutur dengan karyawan rumah sakit, peneliti dan teman dalam satu komunitas, namun mereka melibatkan kehadiran makhluk lain yang tidak dapat dilihat oleh mitra tutur. Hal tersebut karena pikiran mereka dipengaruhi oleh halusinasi dan waham. Halusinasi dan waham tiap penderita berbeda. Yt dengan sub tipe skizofrenia tidak terorganisasi dalam penelitian ini merasa dapat melihat makhluk lain seperti malaikat, hantu, dan sebagainya. Berikut defisit deiksis persona pertama:

\begin{tabular}{|c|c|}
\hline (7) & Interpretasi \\
\hline $\begin{array}{l}\text { Pen : (a) Kok tahu kalau itu obat tidur? } \\
\text { Yt : (b) Tahu, dulu pernah kok di sini, } 2009 \\
\text { sama } 2010 \\
\text { Pen : (c) Ha? Lha sekarang kok ke sini lagi. } \\
\text { Ha? Lha sekarang kok ke sini lagi. }\end{array}$ & $\begin{array}{l}\text { Pen : Kok tahu kalau itu } \\
\text { obat tidur? } \\
\text { Yt : Tahu, dulu pernah kok } \\
\text { di sini, } 2009 \text { dan } 2010 . \\
\text { Pen : Ha? Lha sekarang }\end{array}$ \\
\hline
\end{tabular}

122 | ISSN: 22477-5150 http://journal.unesa.ac.id/index.php/jpi 
Cik betahe kamu.

Kok betahnya kamu.

Yt : (d) Abis itu keluar. Masuk lagi. Aneh aja

Setelah itu keluar. Masuk lagi. Aneh saja

pikirannya, aneh-aneh polih pusing lagi.

pikirannya, aneh-aneh jadi pusing lagi.

Kakehan pikiran.

Kebanyakan pikiran.

Pen : (e) Pikiran apa?

Yt : (f) (menyanyi) Pikiranku tak dapat kumengerti...

Pen : (g) Pikiran apa?

Yt : (h) Lha iya tak dapat dimengerti

Lha iya tidak dapat di mengerti

pikirane, mbuh pikirane dolen sak puase

pikirannya, entah pikirannya main sepuasnya

sampek digoleki (menirukan kata-kata

sampai dicari

ibunya) "endi anakku nok endi?". Nek

"mana anakku dimana?". Kalau

niate wis pamitan dolen gak mulih? gak

niatnya sudah pamitan main tidak pulang? Tidak

mulih, tak bacok koen!

pulang, kubacok kamu!

\section{Konteks}

Pertuturan terjadi di pagi hari antara Pen dengan Yt mengenai sesuatu yang dipikirkan oleh Yt. Saat pertuturan, Yt terlihat tidak bersemangat. Yt sering menundukkan kepala dan tidak menatap Pen saat bertutur.

(DR.Yt.7)

Data (19) tuturan (a) hingga (c) mengenai kembalinya Yt ke RS Jiwa Menur untuk yang ketiga kalinya setelah pernah dirawat pada tahun 2009 dan 2010. Yt menggunakan enklitik -nya untuk merujuk pada dirinya sebagai persona pertama. Yt pada tuturan (h) juga menggunakan sufiks -e pada kata pikiran. Sufiks $-e$ merupakan salah satu bentuk akhiran atau panambang dalam bahasa Jawa yang memiliki arti -nya dalam bahasa Indonesia. Bentuk enklitik -nya pada tuturan Yt di atas merujuk pada dirinya sebagai persona pertama. Sufiks - $e$ pada kok ke sini lagi. Kok betah sekali kamu.

Yt : Setelah itu keluar dari sini. Masuk lagi ke sini. Aneh saja pikirannya, aneh-aneh sehingga pusing lagi. Terlalu banyak yang dipikirkan.

Pen : Pikiran apa?

$Y t$ : (menyanyi) Pikiranku tidak dapat aku mengerti...

Pen : Pikiran apa?

Yt : Lha iya tidak dapat di mengerti pikirannya, entah pikirannya ingin main sepuasnya sampai dicari (menirukan kata-kata sampai dicari ibunya) mana anakku dimana?". Kalau niatnya sudah pamitan main tidak pulang? Tidak pulang, kubacok kamu! 
pikirane dengan sufiks - $e$ pada puase memiliki arti yang berbeda. Sufiks -e pada dolen sak puase merujuk pada waktu bermain yang tidak terbatas.

Data (7) Per sebagai $n$ dan Yt sebagai t. Pada tuturan (d) tampak defisit deiksis ruang yaitu penggunaan enklitik -nya pada kata pikirannya yang merujuk pada dirinya sebagai persona pertama. Sedangkan enklitik -nya dalam bahasa Indonesia digunakan untuk merujuk persona ketiga. Fungsi subjek persona pertama untuk merujuk diri sendiri dalam bahasa Indonesia adalah aku atau saya. Namun $t$ mengganti enklitik $-k u$ sebagai subjek persona pertama untuk merujuk dirinya dengan enklitik -nya sehingga tuturan t tidak gramatikal. Pada saat itu, $\mathrm{t}$ mengalami gangguan bentuk berpikir konkretisasi.

Apabila t tidak mengalami gangguan berpikir konkretisasi terhadap fungsi subjek persona pertama yang merujuk pada dirinya sendiri, maka tuturan tersebut berupa:

*(7) t : $\quad\left(d^{1}\right)$ Abis itu keluar. Masuk lagi. Aneh aja pikiranku, aneh-aneh Setelah itu keluar. Masuk lagi. Aneh saja pikiranku, anehaneh

polih pusing lagi. Kakehan pikiran. jadi pusing lagi. Terlalu banyak pikiran.

Pada tuturan $\left(d^{1}\right) \mathrm{t}$ menunjukkan kesempurnaan dalam menyatakan pronomina persona pertama yang merujuk pada dirinya yaitu $-k u$ pada pikiranku.

Defisit deiksis persona $\mathrm{t}$ selanjutnya terdapat pada tuturan (h) yaitu penggunaan sufiks -e pada kata pikirane yang merujuk pada dirinya sebagai persona pertama. Sedangkan sufiks $-e$ merupakan akhiran atau panambang dalam bahasa Jawa yang memiliki arti -nya dalam bahasa Indonesia. Enklitik nyasebagai pronomina persona dalam bahasa Indonesia merujuk pada persona ketiga. Fungsi subjek persona pertama untuk merujuk diri sendiri dalam bahasa Jawa adalah aku, kula, dhalem. Prefiks dalam bahasa Jawa untuk merujuk subjek persona pertama adalah tak dan dak. Sedangkan sufiks dalam bahasa Jawa untuk merujuk subjek persona pertama adalah $-k u$. Sedangkan sufiks $-e$ dalam bahasa 124 | ISSN: 22477-5150 http://journal.unesa.ac.id/index.php/jpi 
Jawa merujuk pada subjek persona ketiga seperti halnya sufiks -nya dalam bahasa Indonesia. Namun $t$ mengganti enklitik $-k u$ sebagai subjek persona pertama untuk merujuk dirinya dengan enklitik $-e$ sehingga tuturan $t$ tidak gramatikal. Pada saat itu, t mengalami gangguan bentuk berpikir konkritisasi.

Jikat tidak mengalami gangguan berpikir konkretisasi terhadap fungsi subjek persona pertama yang merujuk pada dirinya sendiri, maka tuturan tersebut berupa:

*(7) $\mathrm{t} \quad:\left(\mathrm{h}^{1}\right)$ Lha iya tak dapat dimengerti pikiranku, mbuh pikiranku Lha iya tidak dapat dimengerti pikiranku, entah pikiranku ingin dolen sak puase sampek digoleki (meniru kata-kata ibunya) ingin main sepuasnya sampai dicari

"endi anakku nok endi?". Nek niate wis pamitan dolen gak "mana anakku dimana?". Kalau niatnya sudah pamitan main tidak

mulih? gak mulih, tak bacok koen! pulang? Tidak pulang, kubacok kamu!

Pada tuturan $\left(\mathrm{h}^{1}\right) \mathrm{t}$ menunjukkan kesempurnaan dalam menyatakan pronomina persona pertama yang merujuk pada dirinya yaitu $-k u$ pada pikiranku.

\section{3) Defisit Deiksis Waktu Tuturan Penderita Skizofrenia}

Defisit deiksis waktu tuturan penderita skizofrenia terjadi ketika mereka berada di rumah sakit, namun mereka mengalami kesulitan mengingat waktu yang telah mereka lalui berkaitan dengan aktifitas sehari-hari maupun aktifitas yang baru saja mereka lakukan. Hal tersebut karena pikiran mereka dipengaruhi oleh halusinasi dan waham. Halusinasi dan waham tiap penderita berbeda.

Yt mengalami kesulitan menyebutkan waktu dan mengingat waktu berkaitan dengan aktifitas sehari-hari maupun aktifitas yang baru saja dia lakukan. Berikut defisit deiksis waktu kini:

(8)

Interpretasi 


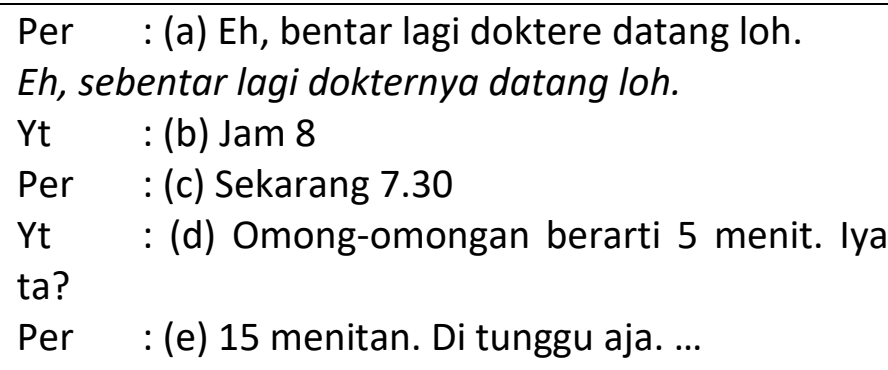

\section{Konteks}

III. Pertuturan antara Per dan Yt terjadi waktu pagi hari. Yt menunggu kedatangan dokter yang datang memeriksa pasien pada hari-hari tertentu di pagi hari sekitar pukul 08.00.

(DW.Yt.8)

Data (8) terjadi antara Per dengan Yt dalam percakapan terapeutik mengenai selang waktu percakapan yang telah dilalui. $\mathrm{n}$ yaitu Per memberikan pernyataan kepada t yaitu Yt pada tuturan (a) mengenai kedatangan dokter ke Ruang Gelatik untuk memeriksa pasien. Yt menanggapi pernyataan Per dengan tuturan (b) bahwa dokter datang dan memeriksa pasien di Ruang Gelatik setiap pukul 08.00 WIB. Meskipun kedatangan dokter untuk memeriksa pasien di Ruang Gelatik tidak dilakukan setiap hari, namun Yt mampu mengingat waktu kedatangan dokter ketika perawat atau karyawan rumah sakit memberikan pengumuman bahwa pada hari tersebut dokter akan datang memeriksa. Per kemudian memberikan pernyataan kepada Yt pada tuturan (c) bahwa saat tuturan berlangsung waktu menunjukkan pukul 07.30 WIB. Yt pada tuturan (d) memberikan pernyataan bahwa percakapan antara mereka berdua telah berlangsung selama 5 menit. Namun Yt juga menanyakan kebenaran pernyataannyanya tersebut pada Per. Per pada tuturan (e) memperbaiki pernyataan Yt bahwa percakapan antara mereka berdua telah berlangsung selama 15 menit.

Data (8) Per sebagai $n$ dan Yt sebagai t. Defisit deiksis waktu t pada tuturan (8) terjadi ketika t memberikan pernyataan (d) bahwa percakapan antara mereka berdua telah berlangsung selama 5 menit. Pada tuturan (b) t memberikan pernyataan bahwa dokter datang pukul 08.00 WIB dan Per memberikan 126 | ISSN: 22477-5150 http://journal.unesa.ac.id/index.php/jpi 
pernyataan (c) bahwa saat tuturan berlangsung waktu menunjukkan pukul 07.30 WIB. Selang waktu antara 07.30 yang dinyatakan oleh $n$ dan 08.00 yang dinyatakan oleh t adalah 15 menit, namun t pada tuturan (c) menyatakan bahwa selang waktu percakapan antara mereka berdua adalah 5 menit. Pada saat itu, $\mathrm{t}$ mengalami gangguan bentuk berpikir konkritisasi. Selang waktu antara 07.30 hingga 08.00 yang seharusnya adalah 15 menit, namun oleh t diganti dengan 5 menit. Pada saat itu, $\mathrm{t}$ mengalami gangguan bentuk berpikir konkretisasi.

Apabila t tidak mengalami gangguan bentuk berpikir konkretisasi terhadap waktu, tuturan tersebut berupa:

*(8) $t \quad:\left(d^{1}\right)$ omong-omongan berarti 15 menit. iya ta?

Pada tuturan $\left(d^{1}\right) \mathrm{t}$ menujukkan kesempurnaan dalam memperhitungkan selang waktu antara 07.30 dengan 08.00 yaitu 15 menit.

\subsection{Defisit Struktur Percakapan Penderita Skizofrenia}

\section{1) Defisit Alih Tutur (Turn Taking)}

Menciptakan merupakan cara mengambil giliran dengan menciptakan inisiasi atau reinisiasi sehingga tercipta pertukaran baru atau berikutnya. Yt memiliki kemampuan menciptakan pertuturan yang baru dengan mitra tutur, namun Yt kesulitan mencari topik.

\begin{tabular}{|c|c|c|}
\hline \multicolumn{2}{|r|}{ (9) } & Interpretasi \\
\hline & $\begin{array}{l}\text { : (a) (menghampiri Pen dan Per sambil } \\
\text { bernyanyi) Maju tak gentar membela yang } \\
\text { benar. Allahu Akbar! (b) Kan dulu gak } \\
\text { banyak partai kan, partai kan cuma satu, PDI } \\
\text { kan. (c) Tiga tok kan partainya. } \\
\text { : (d) Apa aja? }\end{array}$ & $\begin{array}{l}\text { Yt : (menghampiri Pen } \\
\text { dan Per sambil bernyanyi) } \\
\text { Maju tak gentar membela } \\
\text { yang benar. Allahu Akbar! } \\
\text { Kan waktu dulu tidak } \\
\text { banyak partai, dulu partai } \\
\text { hanya ada satu, PDI kan. } \\
\text { Tiga saja kan partainya. } \\
\text { Per: Apa saja? }\end{array}$ \\
\hline \multicolumn{3}{|c|}{$\begin{array}{l}\text { IV. Konteks } \\
\text { V. Yt menghampiri Pen dan Per yang sedang duduk di kursi di depan ruang D3 } \\
\text { kamar pasien. Yt saat itu usai melakukan senam pagi bersama pasien lainnya. Yt } \\
\text { mengangkat tangan kanannya dan mengepalkan telapak tangannya. }\end{array}$} \\
\hline
\end{tabular}

(DAc.Yt.9) 
Data (9) Yt datang menghampiri Pen dan Per dengan mengangkat tangan kanannya dan mengepalkan telapak tangannya sambil bernyanyi (a). Yt memiliki kemampuan menciptakan tuturan (b), namun tuturan yang muncul tersebut tidak sesuai dengan konteks situasi. Sebelum menghampiri mitra tutur, aktifitas yang dilakukan Yt adalah senam pagi bersama pasien lain. Aktifitas tersebut tidak jauh dari tempat mitra tutur berada. Sehingga mitra tutur mengetahui bahwa tuturan Yt tidak berkaitan dengan aktifitas yang dilakukan oleh Yt sebelumnya.

Data (26) Yt sebagai $n$ dan Per sebagai t. Defisit unsur percakapan berupa alih tutur menciptakan tampak pada tuturan (a). Topik tuturan yang diciptakan $n$ muncul dengan tiba-tiba tanpa diawali dengan membuka topik tuturan berkaitan dengan partai politik. $\mathrm{n}$ pada tuturan (b) meyakinkan $\mathrm{t}$ bahwa dulu hanya ada satu partai politik, yaitu PDI. Namun t pada tuturan (c) menyatakan hal yang berbeda dari tuturan (b) yaitu dulu hanya ada tiga partai politik.

Tuturan yang diciptakan $\mathrm{n}$, ditujukan pada $\mathrm{t}$ yang pada awalnya tidak bertutur mengenai partai politik. $t$ pada tuturan (d) merespon tuturan $n$ dengan memberikan pertanyaan. Hal tersebut dilakukan oleh $\mathrm{n}$ agar $\mathrm{t}$ merasa bahwa tuturannya diperhatikan dan $\mathrm{n}$ dapat bergabung dalam peristiwa tutur tanpa diminta.

Jika $\mathrm{n}$ mengawali tuturan dengan pertanyaan mengenai topik yang hendak dibicarakan dengan mitra tutur, maka dapat dikatakan bahwa $\mathrm{n}$ mampu memahami unsur percakapan berupa alih tutur menciptakan, seperti:

*(9) $\mathrm{n} \quad:\left(a^{1}\right)$ (menghampiri Pen dan Per sambil bernyanyi) Maju tak gentar membela yang benar, Allahu Akbar. (b1) Mbak tahu atau tidak, dulu ada berapa partai? Setahuku hanya ada satu, PDI saja. $\left(c^{1}\right)$ Tapi ada juga yang mengatakan kalau dulu ada tiga partai.

Data ${ }^{*}(9) \mathrm{n}$ dapat menciptakan tuturan $\left(\mathrm{b}^{1}\right)$ dengan bertanya terlebih dahulu mengenai pengetahuan $t$ terhadap partai politik. Kemudian $n$ menyampaikan pengetahuannya mengenai partai politik. 


\section{2) Tumpang Tindih (Overlap)}

Tumpang tindih (overlap) terjadi ketika mitra tuturnya belum selesai bertutur. Cara tersebut dilakukan Yt ketika ingin mendapatkan perhatian dari mitra tuturnya, selain itu juga ketika Yt tidak setuju dengan tuturan mitra tutur.

\begin{tabular}{|c|c|c|}
\hline & (10) & Interpretasi \\
\hline Per & $\begin{array}{l}\text { (a) Kalau psikolog tu kamu cuma ditanya- } \\
\text { tanya aja. (b) Gak diperiksa //gigimu } \\
\text { : (c) Aku wis ngerti! Di rubung semut, } \\
\text { Aku sudah mengerti! Di kerubuti semut, } \\
\text { tak biarkan. Gak sakit kok. } \\
\text { kubiarkan. Tidak sakit kok. }\end{array}$ & $\begin{array}{l}\text { Per : Kalau psikolog itu } \\
\text { kamu hanya ditanya-tanya } \\
\text { saja. Tidak } \\
\text { diperiksa//gigimu. } \\
\text { Yt : Aku sudah mengerti! Di } \\
\text { kerubuti oleh semut, aku } \\
\text { biarkan. Tidak sakit kok. }\end{array}$ \\
\hline & $\begin{array}{l}\text { VI. Konteks } \\
\text { Ketika bertutur dengan Per, Yt duduk } \\
\text { ndarkan tubuhnya di kursi. Ketika Per ber } \\
\text { nya ke mulut dan meraba giginya. }\end{array}$ & $\begin{array}{l}\text { kursi dengan bersila dan } \\
\text { tur (a), Yt memasukkan jari }\end{array}$ \\
\hline
\end{tabular}

(DAr.Yt.10)

Data (10) Per menyatakan pada Yt pada tuturan (a) bahwa tugas psikolog adalah memberi pertanyaan mengenai sesuatu yang dipikirkan dan dirasakan oleh Yt. Kemudian Per pada tuturan (b) hendak menyampaikan pada Yt bahwa psikolog tidak bertugas memeriksa gigi Yt. Namun ketika Per belum selesai menyatakan (b), Yt sudah menyela tuturan Per dengan memberi pernyataan (c) bahwa dirinya merasa sudah tahu bahwa tugas psikolog bukanlah memeriksa gigi. Sehingga tuturan Per dengan Yt tumpang tindih.

Data (10) Per sebagai $\mathrm{n}$ dan Yt sebagai t. Tumpang tindih t tampak ketika $\mathrm{t}$ merasa sudah memahami maksud tuturan $n$, bahwa seorang psikolog tidak bertugas memeriksa gigi. Sehingga dia menyela tuturan $\mathrm{n}$ tanpa memberi kesempatan pada $\mathrm{n}$ untuk menyelesaikan tuturannya.

Jika t membiarkan $\mathrm{n}$ menyelesaikan tuturannya kemudian memberi respon berupa jawaban atau pernyataan, maka tidak akan terjadi tumpang tindih tuturan. Selain itu, $\mathrm{t}$ dapat mengetahui dengan jelas maksud yang disampaikan 
oleh $\mathrm{n}$ sehingga $\mathrm{t}$ dapat memberikan pernyataan sesuai dengan maksud tuturan n. Tuturan tersebut tidak akan mengalami tumpang tindih tuturan apabila tuturan tersebut berupa:

*(10) $\mathrm{n} \quad$ : ( $\left.\mathrm{a}^{1}\right)$ Kalau psikolog tu kamu cuma ditanya-tanya aja. $\left(\mathrm{b}^{1}\right)$ Gak diperiksa gigimu.

t $\quad:\left(c^{1}\right)$ Aku wis ngerti! Di rubung semut, tak biarkan. Gak Aku sudah mengerti! Di kerubuti semut, kubiarkan. Tidak sakit kok.

sakit kok.

Pada data *(10), t menunjukkan kesempurnaan dalam memahami struktur percakapan. $t$ membiarkan $n$ menyelesaikan tuturan $\left(b^{1}\right)$ sehingga t mengetahui maksud tuturan $\mathrm{n}$, kemudian $\mathrm{t}$ merespon tuturan $\mathrm{n}$ dengan memberikan pernyataan $\left(c^{1}\right)$ yang sesuai dengan maksud tuturan $n$.

\section{3) Defisit Pasangan Ujaran Terdekat (Adjacency Pairs)}

\section{(1) Pasangan tanya jawab}

Pasangan tanya jawab merupakan dua pasangan ujaran yang berupa pertanyaan dan jawaban. Ujaran yang pertama berupa kalimat pertanyaan dan ujaran yang kedua berupa jawaban. Apabila dalam sebuah percakapan penutur mengajukan pertanyaan, sudah selayaknya mitra tutur memberikan jawaban yang relevan dengan pertanyaan penutur.

Pasangan tanya jawab antara Yt dengan mitra tuturnya dapat berlangsung dengan baik, namun kadangkala juga mengalami defisit. Di saat mitra tutur memberikan pertanyaan, Yt bertanya balik kepada mitra tuturnya. Selain itu, ketika mitra tutur memberikan pertanyaan, Yt tidak menjawab, tetapi hanya diam dengan pandangan kosong atau bahkan berlalu meninggalkan mitra tuturnya.

\begin{tabular}{|c|c|c|}
\hline & (11) & Interpretasi \\
\hline & $\begin{array}{l}\text { : (a) Minuman favoritmu apa? } \\
\text { : (b) Pokoke sepakbola. } \\
\text { Pokoknya sepakbola. }\end{array}$ & $\begin{array}{l}\text { Per : Minuman favoritmu } \\
\text { apa? } \\
\text { Yt: Pokoknya sepakbola. }\end{array}$ \\
\hline
\end{tabular}

130 | ISSN: 22477-5150 http://journal.unesa.ac.id/index.php/jpi 


\section{Konteks}

VIII.Per dan Yt duduk di kursi. Saat bertutur, Yt tidak menatap wajah Per. Yt memainkan pulpen dengan tangan kanannya.

(DPtj.Yt.11)

Data (11) Per bertanya pada Yt mengenai minuman favorit Yt. Yt pada tuturan (b) memberikan penegasan dengan kata pokoke yang berarti yang terpenting adalah sepakbola.

Data (11) Per sebagai $n$ dan Yt sebagai t. Defisit pasangan ujaran terdekat Yt berupa pasangan tanya jawab tampak pada tuturan (b). t tidak memahami bentuk pertanyaan (a). Jawaban sepakbola pada tuturan (b) tidak relevan dengan pertanyaan (a) mengenai minuman. Referen yang ditunjuk oleh $\mathrm{n}$ adalah minuman berupa benda cair. Sedangkan jawaban yang diberikan oleh $t$ adalah sepakbola. Jawaban sepakbola tentu akan relevan apabila $\mathrm{n}$ bertanya mengenai hobi t. Apabila data (11) dideskripsikan dengan bagan akan tampak sebagai berikut:

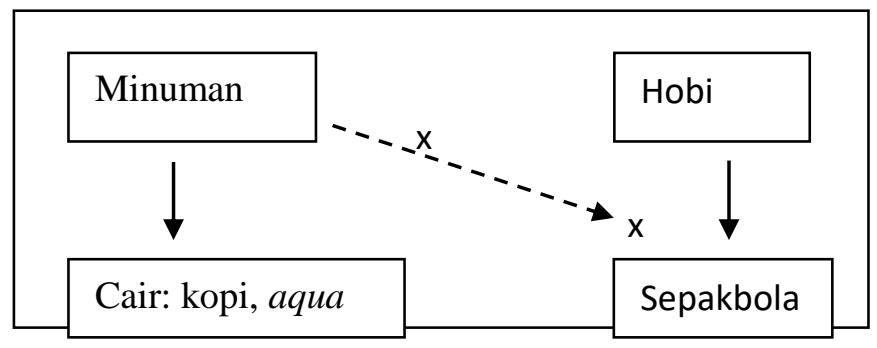

Pada data (30), t memahami pasangan ujaran terdekat berupa pasangan tanya jawab jika tuturan tersebut berupa:

$*(11)$ t $\quad:\left(b^{1}\right)$ kopi.

Pada tuturan $\left(b^{1}\right)$, t memahami pasangan ujaran terdekat berupa pasangan tanya jawab. t memahami tuturan (a) merupakan pertanyaan, sehingga t merespon dengan memberi jawaban yang relevan.

\section{(2) Pasangan keluhan-alasan}


Keluhan merupakan tindak tutur yang diungkapkan karena pembicara tidak menyukai atau tidak puas atas sesuatu yang dilakukan atau ditampilkan oleh pendengarnya. Ytkadangkala mengeluh karena sakit atau karena sesuatu yang mengganggunya. Namun dia kesulitan mendeskripsikan sakit yang dikeluhkan atau sesuatu yang mengganggunya berkaitan dengan halusinasi.

\begin{tabular}{|c|c|}
\hline (12) & Interpretasi \\
\hline $\begin{array}{l}\text { Yt : (a) Ojok diece ta mbak. Lucu aku ini, } \\
\text { Jangan diejek lah mbak. Lucu aku ini, } \\
\text { ndak pernah sedih aku, (b) sedih dhiluk- } \\
\text { tidak pernah sedih aku, sedih sebentar- } \\
\text { dhiluk aku. Rong menit wis cukup. } \\
\text { sebentar aku. Dua menit sudah cukup. } \\
\text { Per : (c) Lha apa lho yang membuat kamu sedih? } \\
\text { Yt : (d) Ya ndak tahu mbak. (e) Ngkok, nok } \\
\text { Ya tidak tahu mbak. Nanti, di } \\
\text { omah diuring-uringi emak terus. } \\
\text { rumah dimarah-marahi emak terus. } \\
\text { Per : (f) Kenapa? } \\
\text { Yt : (g) Gak dituruti minta belikan rokok, } \\
\text { Tidak dituruti minta dibelikan rokok, } \\
\text { gak ditukokna. } \\
\text { tidak dibelikan. }\end{array}$ & $\begin{array}{l}\text { Yt: Jangan diejek lah mbak. } \\
\text { Lucu aku ini, tidak pernah } \\
\text { sedih aku, sedih sebentar- } \\
\text { sebentar aku. Dua menit } \\
\text { sudah cukup. } \\
\text { Per : Lha apa Iho yang } \\
\text { membuat kamu sedih? } \\
\text { Yt : Ya tidak tahu mbak. } \\
\text { Nanti, di rumah dimarah- } \\
\text { marahi emak terus. } \\
\text { Per: mengapa? } \\
\text { Yt: Tidak dituruti (emak) jika } \\
\text { aku minta dibelikan rokok, } \\
\text { tidak dibelikan. }\end{array}$ \\
\hline IX. Konteks & \\
\hline
\end{tabular}

(DPka.Yt.12)

Data (12) Yt pada tuturan (a) menyatakan pada Per bahwa dirinya lucu yang berarti dirinya selalu gembira dan tidak pernah bersedih. Namun Yt pada tuturan (b) juga menyatakan apabila dia bersedih cukup dua menit. Per pada tuturan (c) bertanya pada Yt mengenai sesuatu yang dikeluhkan. Yt pada tuturan (d) menjawab tidak tahu mengapa dia bersedih. Namun, Yt pada tuturan (e) mengeluh bahwa dirinya bersedih, karena jika dia berada di rumah, maka dia sering dimarahi oleh ibunya. Per pada tuturan (f) menanyakan penyebab Yt mengeluh (g). Yt pada tuturan (f) menyatakan alasan mengapa dia sering 
dimarahi oleh ibunya yaitu karena keinginannya untuk membeli rokok tidak dipenuhi oleh ibunya.

Data (12) Yt sebagai $n$ dan Per sebagai t. Defisit pasangan ujaran terdekat berupa pasangan tanya jawab keluhan-alasan oleh $\mathrm{n}$ tampak pada tuturan (a) dan (b). n pada tuturan (a) dan (b) memberikan pernyataan yang saling bertolak belakang. Tuturan (a), n menyatakan bahwa dirinya tidak pernah bersedih, namun pada tuturan (b) selanjutnya $\mathrm{n}$ menyatakan bahwa apabila dirinya bersedih hanya membutuhkan waktu dua menit. Hal ini berarti tuturan (b) berupa keluhan, mengingkari tuturan (a). Begitu pula tuturan (d) dan (e). Tuturan (e) menyatakan bahwa $\mathrm{n}$ tidak tahu apa yang membuatnya bersedih. Namun pada tuturan (f) $n$ menyatakan sebaliknya, $n$ mengeluh jika dia berada di rumah, maka dia akan sering dimarahi oleh ibunya. $\mathrm{n}$ sebenarnya ingin menyampaikan bentuk kekecewaannya terhadap ibunya namun $\mathrm{n}$ kesulitan menyampaikan dalam bentuk tuturan. Secara klinis, tuturan $\mathrm{n}$ tersebut merupakan gangguan bentuk berpikir konkretisasi.

Tuturan (a) tidak akan mengalami defisit pasangan ujaran terdekat berupa pasangan keluhan-alasan apabila tuturan tersebut berupa:

*(12) t : (a $\left.a^{1}\right)$ Ojok diece ta mbak.Lucu aku ini, aku pernah sedih, (b $\left.b^{1}\right)$ tapi Jangan diejek lah mbak. Lucu aku ini, aku pernah sedih, tetapi sedihku dhiluk-dhiluk. Rong menit wis cukup. sedihku sebentar-sebentar, dua menit sudah cukup. dan

: (d') Seperti yang pernah kukatakan mbak $\left(e^{1}\right)$ Ngkok, nok omah diuring-uringi emak terus.

Nanti, di rumah selalu dimarahi emak.

Data $*(12)$ n menunjukkan kesempurnaan memahami pasangan ujaran terdekat berupa pasangan keluhan-alasan.

\subsection{Defisit Relevansi Tuturan Penderita Skizofrenia}

Defisit relevansi tuturan adalah ketidaksempurnaan mengaitkan informasi baru dengan informasi lama yang pernah dituturkan berkaitan dengan deiksis. 
Ketidaksempurnaan tersebut tampak ketika Yt tidak mampu mengingat sesuatu yang pernah dituturkan berkaitan dengan informasi baru yang sedang dituturkan. Selain itu, ketidaksempurnaan merelevansikan tuturan tampak ketika Yt salah menafsirkan atau memahami maksud ujaran mitra tutur sehingga jawaban yang diberikan Yt tidak sesuai dengan yang diinginkan oleh mitra tutur.

Defisit relevansi tuturan Yt dianalisis berdasarkan inferensi mitra tutur yang diperoleh melalui efek kognisi, dan berdasarkan penyampaian Yt melalui komunikasi ostensif.

\begin{tabular}{|c|c|}
\hline (13) & Interpretasi \\
\hline $\begin{array}{l}\text { Pen : (a) Yt yang kamu pikirkan apa sih? } \\
\text { Yt } \quad \text { (b) aku gak kuat } \\
\text { Pen : (c) apa? } \\
\text { Yt } \quad \text { (d) di bujuki terus bu } \\
\text { Pen : (e) di bujuki siapa? } \\
\text { Yt : (f) apik ambek apik jadinya plus-plus. } \\
\text { Baik dengan baik jadinya plus-plus. } \\
\text { Kalau plus jadi min. Biar imbang plus- } \\
\text { Kalau plus jadi min. biar imbang plus } \\
\text { pluse gini, jadi mine gini (sambil } \\
\text { plusnya begini, jadi minnya begini (sambil } \\
\text { memainkan jari-jari tangannya). Jadi plus } \\
\text { memainkan jari-jari tangannya). Jadi plus } \\
\text { min plus min plus min mesti sithik. } \\
\text { min plus min plus min pasti sedikit. } \\
\text { Imbange sepuluh plus dikurangi lima min } \\
\text { Imbangnya sepuluh plus dikurangi lima min } \\
\text { dikurangi lima belas min berapa hasilnya? } \\
\text { dikurangi lima belas min berapa hasilnya? }\end{array}$ & $\begin{array}{l}\text { Pen : Yt yang kamu pikirkan } \\
\text { apa sih? } \\
\text { Yt : Aku tidak sanggup } \\
\text { Pen : Apa? } \\
\text { Yt : Di bohongi terus bu } \\
\text { Pen : Di bohongi siapa? } \\
\text { Yt : Baik dengan baik jadinya } \\
\text { plus-plus. Kalau plus jadi } \\
\text { min. Biar seimbang plu- } \\
\text { plusnya begini, jadi } \\
\text { minnya begini (sambil } \\
\text { memainkan jari-jari } \\
\text { tangannya). Jadi plus } \\
\text { min plus min plus min } \\
\text { pasti sedikit. } \\
\text { Seimbangnya sepuluh } \\
\text { plus dikurangi lima min } \\
\text { dikurangi lima belas min } \\
\text { berapa hasilnya? }\end{array}$ \\
\hline $\begin{array}{l}\text { Yt sambil minum secangkir kopi, duc } \\
\text { Per. Saat bertutur, Yt tidak menatap Pen ma } \\
\text { depan ke arah taman. Benda yang menjad } \\
\text { papaya yang berada di sudut taman. Pad } \\
\text { sebuah kayu kecil memanjang yang ter } \\
\text { membentuk tanda + "plus". }\end{array}$ & $\begin{array}{l}\text { nping Pen dengan ditemani } \\
\text { r. Matanya melihat lurus ke } \\
\text { perhatiannya adalah pohon } \\
\text { papaya tersebut terdapat } \\
\text { ditengah batang sehingga }\end{array}$ \\
\hline
\end{tabular}


Pen pada tuturan (a) bertanya pada Yt mengenai sesuatu yang dipikirkan. Tuturan (b) Yt menjawab bahwa dirinya tidak kuat. Pen pada tuturan (c) bertanya pada Yt mengenai sesuatu yang membuat Yt merasa tidak kuat. Tuturan (d) Yt menjawab bahwa dirinya merasa tidak kuat karena dibohongi.

Pen pada tuturan (e) bertanya pada Yt mengenai seseorang yang telah membohonginya. Tuturan (f) Yt tampak tidak relevan dengan pertanyaan yang diberikan oleh Pen pada tuturan (e). Apabila dideskripsikan dengan bagan, maka tuturan (e) dan (f) akan tampak sebagai berikut:

\begin{tabular}{|c|l|}
\hline Pertanyaan (e): Persona & Jawaban (f): tanda numeric \\
\hline Siapa? -dia & -plus \\
-mereka & -min \\
-Hendra & \\
\hline
\end{tabular}

Pen sebagai $\mathrm{n}$ dan Yt sebagai t. Defisit relevansi tuturan $\mathrm{t}$ tampak ketika $\mathrm{n}$ bertanya mengenai siapa yang membohongi t. Siapa pada tuturan (e) merujuk pada persona. Namun jawaban $\mathrm{t}$ kelura dari topik tuturan. $\mathrm{t}$ menjawab menggunakan tanda-tanda numerik 'plus minus' yang tidak ada hubungannya dengan pertanyaan $\mathrm{n}$. Sehingga menimbulkan salah paham terhadap Pen.

Pada saat bertutur (f), t melihat lurus ke depan ke arah pohon papaya yang berada di sudut taman. $t$ mengalami disorientasi terhadap pertanyaan yang diajukan oleh $\mathrm{n}$ dengan sesuatu yang dipikirkan ketika melihat sebuah kayu tertancap di batang pohon pepaya dan membentuk tanda "+" sehingga jawaban yang muncul berupa tanda numerial "plus-minus". Tuturan (f) tersebut tentu saja tidak menjawab dengan benar pertanyaan $n$ pada tuturan (e). Sehingga dapat dikatakan bahwa tuturan (f) tersebut tidak relevan. Saat itu, t mengalami gangguan bentuk berpikir berupa asosiasi longgar yaitu jawaban t tidak relevan dengan pertanyaan $\mathrm{n}$. 
Selain jawaban t pada tuturan (f) tidak relevan dengan pertanyaan $\mathrm{n}$ pada tuturan (e), berdasarkan efek kognisi $n, t$ pernah menyatakan bahwa t merasa dibujuki Per karena selalu diingatkan untuk teratur minum obat agar sembuh dan cepat pulang ke rumah. Tuturan (f) memiliki derajat relevansi yang lemah, karena tuturan (f) yang berupa jawaban tidak relevan dengan tuturan (e) yang berupa pertanyaan. Sehingga $n$ memerlukan waktu yang cukup lama untuk dapat menentukan relevansi tuturan $\mathrm{t}$.

Tuturan t akan relevan apabila t menjawab:

$*(13) \mathrm{t}:\left(f^{1}\right)$ perawat.

Pertanyaan $\mathrm{n}$ pada tuturan (e) mengenai siapa yang merujuk pada persona dijawab oleh t pada tuturan $\left(f^{1}\right)$ dengan merujuk pada persona pula. Selain itu, jika merujuk pada tuturan $\mathrm{t}$ sebelumnya tentu akan relevan yaitu seperti ketika $\mathrm{t}$ merasa dibohongi oleh perawat ketika diminta meminum obat agar cepat sembuh.

\subsection{Terapeutik Terhadap Pemulihan Defisit Pragmatik Tuturan Penderita} Skizofrenia

Dalam studi kasus terhadap Yt, perawat sebagai ahli klinis yang menangani Yt melatih keterampilan Yt untuk berkomunikasi sesuai bentuk gangguan berpikirnya dengan terapeutik verbal. Terapeutik perawat terhadap Yt dilakukan setiap perawat bertatap muka dengan Yt tanpa dikondisikan waktu maupun tempat.

Jenis terapeutik yang paling lazim digunakan dalam pelayanan keperawatan di rumah sakit adalah secara verbal terutama pembicaraan dengan tatap muka. Terapeutik verbal biasanya lebih akurat dan tepat waktu. Keuntungan terapeutik verbal dalam tatap muka yaitu memungkinkan Ytmemberikan respon secara langsung.

Banyak istilah teknis yang digunakan dalam klinis, namun perawat menyampaikanpesan dengan istilah yang dimengerti Yt. Terapeutik verbal 136 | ISSN: 22477-5150 http://journal.unesa.ac.id/index.php/jpi 
perawat pada Yt menggunakan tuturan yang mudah dipahami oleh Yt. Terapeutik guna membantu memulihkan defisit pragmatik terhadap Yt berkaitan dengan deiksis dan relevansi tuturan. Tuturan-tuturan yang bertujuan untuk memotivasi Yt agar cepat sembuh dengan teratur minum obat, mengikuti olah raga secara teratur, istirahat teratur dan meyakinkan Yt bahwa halusinasi yang dilihat dan waham yang diderita berangsur hilang.

Selain itu, komunikasi verbal akan lebih bermakna jika pesan yang disampaikan berkaitan dengan minat dan kebutuhan pasien. Pawa tahap awal atau tahap orientasi, perawat akan mendukung dan memercayai segala halusinasi dan waham yang disampikan oleh Yt. Tahap berikutnya atau tahap kerja, perawat akan mengarahkan dan meyakinkan Yt bahwa halusinasi yang dilihat dan dirasakan sebenarnya tidak ada. Pada tahap ini biasanya perawat memanfaatkan peneliti, perawat lain, dan teman-teman satu komunitas Yt untuk membenarkan pernyataannya dengan harapan Yt meyakini halusinasi yang dilihat dan dirasakannya serta waham yang dideritanya tidak nyata. Pada tahap akhir atau tahap terminasi, perawat akan mengevaluasi sikap Yt ketika bertutur, mengarahkan Yt untuk bersikap baik dengan orang lain, dan memotivasi Yt agar tidak merasa rendah diri setelah keluar dari rumah sakit.

Data (14) berikut merupakan terapeutik verbal perawat terhadap defisit deiksis ruang oleh $\mathrm{Yt}$ :

\begin{tabular}{|c|c|}
\hline (14) & Interpretasi \\
\hline $\begin{array}{l}\text { Per (a) Trus kalau kamu di sini, yang manen } \\
\text { Terus kalau kamu di sini, yang memanen } \\
\text { siapa? } \\
\text { siapa? } \\
\text { Yt : (b) Aku mbak, lho tak ambil dari sini } \\
\text { Aku mbak, Iho kuambil dari sini } \\
\text { kan bisa. Emak paling, juga manen. } \\
\text { kan bisa. Emak mungkin, juga memanen. } \\
\text { Per : (c) Ya ndak bisa. Rumahmu itu jauh, di } \\
\text { Ya tidak bisa. Rumahmu itu jauh, di } \\
\text { Jombang. (d) Kamu tahu ndak, sekarang }\end{array}$ & $\begin{array}{l}\text { Yt : Aku mbak, Iho } \\
\text { kuambil dari sini kan bisa. } \\
\text { Emak mungkin, juga } \\
\text { memanen. } \\
\text { Per: Ya tidak bisa. }\end{array}$ \\
\hline
\end{tabular}


Jombang. Kamu tahu tidak, sekarang

di mana? Mosok lali?!

di mana? Masa lupa?!

Yt : (e) Rumah sakit lah. Ngunu takon

Rumah sakit lah. Begitu tanya maneh.

lagi.
Rumahmu itu jauh, di Jombang. Kamu tahu tidak, sekarang kamu di mana? Masa lupa?

Yt : Rumah sakit lah. Begitu Tanya lagi.

\section{Konteks}

Terapeutik antara perawat dengan Yt. Peneliti hadir dalam situasi tutur. Yt menggambarkan aktifitas yang dilakukannya ketika memanen tanaman buah di rumah dengan menggambar pada selembar kertas.

(Tr.Yt.14)

Per pada tuturan (c) menyatakan pada Yt bahwa sesuatu yang jauh yaitu tanaman buah yang berada dirumahnya tidak mungkin dapat dipetik dari rumah sakit melalui selembar kertas yang digambar Yt. Selanjutnya, Per pada tuturan (d) bertanya pada Yt mengenai lokasi keberadaannya. Yt menjawab (e) bahwa dia berada di rumah sakit.

Data (14) Per sebagai $\mathrm{n}$ dan Yt sebagai t. Terapeutik $\mathrm{n}$ tampak pada tuturan (c) yaitu $\mathrm{n}$ memperbaiki defisit deiksis ruang $\mathrm{t}$ dengan menyatakan bahwa sesuatu yang berada jauh dan tidak tampak oleh mata, tidak mungkin dapat dijangkau ketika seseorang berada ditempat lain. Selanjutnya $\mathrm{n}$ menguji kemampuan berpikir $\mathrm{t}$ terhadap ruang pada tuturan (d) dengan bertanya pada $\mathrm{t}$ mengenai keberadaannya saat itu. t pada tuturan (e) menjawab dengan benar pertanyaan (d). t sudah sering mendapat pertanyaan serupa dari dokter maupun perawat. Bahkan ketika t mengalami defisit deiksis ruang tersebut di waktu yang berbeda, ahli klinis yang menangani t selalu mengingatkannya.

\section{SIMPULAN}

Sesuai dengan fokus dan tujuan penelitian yang telah diajukan pada bab sebelumnya, serta setelah melewati penganalisisan data, dapat ditarik simpulan berkenaan dengan defisit pragmatik tuturan penderita skizofrenia di RS Jiwa Menur Surabaya studi kasus terhadap pasien bernama Yt. 
Pertama, ditemukan defisit tindak tutur sebagai akibat terganggunya pikiran Yt berupa asosiasi longgar dan konkretisasi. Yt memiliki kemampuan berkomunikasi dengan baik. Namun tuturan Yt seringkali mengalami lompatan topik sehingga maksud tuturan tidak tersampaikan dengan baik. Yt memiliki kemampuan menyebutkan sesuatu yang dilihat dan dirasakan. Namun dia mengalami kesulitan mendeskripsikan sesuatu yang dilihat dan dirasakan tersebut.

Kedua, ditemukan defisit deiksis luar tuturan. Yt mengalami ketidaksempurnaan dalam merujuk sesuatu hal berkaitan dengan ruang, persona, dan waktu. Hal tersebut seringkali muncul ketika halusinasi dan waham yang diderita muncul. Defisit deiksis ruang oleh Yt berkaitan dengan ruang atau tempat yang pernah dikunjungi Yt seperti di kota Surabaya. Yt mengetahui beberapa wilayah di kota Surabaya, namun dia memiliki ketidaksempurnaan dalam mengingat secara abstrak wilayah di kota Surabaya yang pernah dikunjunginya, seperti arah jalan atau alamat tempat yang dia rujuk. Defisit deiksis ruang oleh Yt berikutnya berkaitan dengan ruang atau tempat yaitu rumah Yt. Yt memiliki kemampuan untuk mengingat secara konkret rumah dan tanaman yang berada disekitarnya. Namun dia memiliki ketidaksempurnaan mengingat secara abstrak letak, wujud atau bentuk rumah dan letak tanaman tersebut. Defisit deiksis persona oleh Yt seringkali muncul berupa halusinasi dan waham. Yt menunjuk dirinya sebagai Tuhan, tokoh kartun, tokoh masyarakat, dsb. Yt juga merasa pernah bertemu dengan Nabi, hantu, dsb. Defisit deiksis waktu oleh Yt tidak banyak muncul dalam peristiwa tutur. Defisit deiksis waktu oleh Yt muncul berupa ketidaksempurnaan mengingat hari, jam, dan lamanya waktu atau selang waktu dalam hitungan minggu.

Ketiga, ditemukan defisit struktur percakapan meliputi alih tutur, tumpang tindih dan pasangan ujaran terdekat. Yt menunjukkan defisit alih tutur ketika menciptakan atau mengawali tuturan. Yt memiliki kemampuan untuk 
menciptakan atau mengawali tuturan. Namun ketika menciptakan atau mengawali tuturan, Yt tidak memerhatikan konteks situasi tuturan. Sehingga tuturan yang diciptakan tidak berkaitan dengan konteks situasi yang melibatkan Yt dan mitra tutur. Hal tersebut mengakibatkan mitra tutur kesulitan menentukan maksud tuturan Yt.

Tumpang tindih tuturan Yt terjadi ketika mitra tutur belum menyelesaikan tuturannya, namun Yt menyela. Namun mitra tutur masih melanjutkan tuturannya hingga selesai. Tumpang tindih tuturan mitra tutur dengan Yt disebabkan oleh ketidaksukaan Yt terhadap pernyataan mitra tutur sehingga dia merasa perlu memerbaiki tuturan mitra tutur. Selain itu, tumpang tindih tuturan terjadi ketika Yt merasa lebih tahu tentang suatu hal yang dinyatakan oleh mitra tutur. Tumpang tindih tuturan Yt terhadap mitra tutur adakalanya tidak koheren atau keluar dari topik yang dituturkan oleh mitra tutur.

Defisit pasangan ujaran terdekat tuturan Yt terjadi pada saat terjadi tanyajawab antara Yt dengan mitra tutur. Selain itu juga terjadi saat Yt mengeluh dan memberikan alasan terhadap sesuatu yang dikeluhkan. Yt memiliki kemampuan memahami tuturan mitra tutur berupa pertanyaan, sehingga dia merespon dengan memberi jawaban. Namun jawaban Yt tidak sesuai atau keluar dari topik yang ditanyakan oleh mitra tutur. Selain itu, pertanyaan yang diberikan oleh mitra tutur, ada kalanya direspon dengan memberi pertanyaan kembali pada mitra tutur. Selain keluar dari topik, tuturan Yt panjang lebar sehingga mempersulit mitra tutur menentukan maksud tuturan Yt.

Defisit pasangan ujaran terdekat berupa pasangan keluhan alasan terjadi Yt mengeluhkan sesuatu yang dirasakan, seperti sakit kepala, sakit hati, dan mengeluh karena merindukan rumah dan keluarga yang berada di Jombang. Sesuatu yang dikeluhkan tersebut mengalami defisit saat Yt kesulitan memberikan alasan atau mendeskripsikan rasa sakit atau rindu yang dirasakan. Saat itu Yt mengalami gangguan bentuk berpikir berupa konkretisasi. 
Keempat, ditemukan defisit relevansi tuturan penderita skizofrenia. Yt mengalami ketidaksempurnaan mengingat dan mengaitkan informasi lama yang pernah dituturkan dengan informasi baru yang sedang dituturkan sehingga tuturan yang dihasilkan seringkali tidak relevan.

Kelima, terapeutik perawat terhadap penderita skizofrenia. Yt kadangkala menunjukkan penyangkalan terhadap terapeutik perawat. Namun Yt juga menunjukkan sikap memahami terapeutik perawat. Defisit pragmatik tuturan penderita skizofrenia dapat pulih seiring dengan pengobatan biomedis dan terapeutik dari perawat dan dukungan dari keluarga.

Defisit pragmatik tuturan penderita skizofrenia di RS Jiwa Menur Surabaya diawali dengan defisit kognitif. Defisit kognitif penderita skizorenia tidak selalu Nampak ketika bertutur. Defisit kognitif penderita skizofrenia akan tampak ketika halusinasi dan waham yang diderita muncul. Dalam keadaan sadar atau sedang tidak dipengaruhi halusinasi dan waham, mereka dapat berinteraksi baik dan bertutur baik dengan mitra tutur. sehingga dapat dikatakan bahwa defisit pragmatik tuturan penderita skizofrenia terjadi setelah pikiran mereka terganggu.

\section{DAFTAR RUJUKAN}

Cummings, Louise. 2007. Pragmatik (Sebuah Perspektif Multidisipliner). Yogyakarta: Pustaka Pelajar.

Cummings, Louise. 2010. Pragmatik Klinis: Kajian Tentang Penggunaan dan Gangguan Bahasa Secara Klinis. Yogyakarta: Pustaka Pelajar.

Denzin, Norman K. \& Yvonna S. Lincoln. (Eds). 2000. Handbook of Qualitative Reseach. Second Edition. Thousand Oaks. Sage Publications, Inc.

Darma, Yoce Aliah. 2009. Analisis Wacana Kritis. Bandung: Yrama Widya.

Mahsun. 2005. Metode Penelitian Bahasa: Tahapan Strategi, Metode dan Tekniknya. Jakarta: PT Raja Grafindo Persada.

Maulana, Heri.D.J. 2009. Promosi Kesehatan. Jakarta: EGC

Tomb, David A. 2004. Psikiatri. Jakarta: EGC

Wiramihardja, Sutardjo A. 2005. Pengantar Psikologi Abnormal. Bandung: Refika Aditama 